Journal of Conflict \& Security Law (C) Oxford University Press 2008; all rights reserved. For permissions, please e-mail: journals.permissions@oxfordjournals.org

doi: $10.1093 / \mathrm{jcsl} / \mathrm{krn} 015$

Advance Access published on August 12, 2008

\title{
A Response to Amos Guiora: Reassessing the Parameters of Use of Force in the Age of Terrorism
}

\author{
Muge Kinacioglu*
}

\begin{abstract}
This commentary examines the "strict-scrutiny" approach to self-defence as proposed by Professor Amos N. Guiora and analyzes whether it provides for a clear guideline as to when states may carry out pre-emptive and anticipatory action against a non-state actor. It reviews the existing concepts of the right of selfdefence and pre-emption under international law, with special emphasis on the prevailing debates stemming from contesting interpretations of the related law. In addition, the commentary assesses the relevant decisions in international litigation and state practice to shed light on the application of the conditions for admissible use of force in specific instances of the use of force. In the second part, the commentary critically examines the merits and applicability of Professor Guiora's proposal. It concludes that when there is an international organization (United Nations) which is empowered as a world court, the utility of such domestic mechanism would be limited in terms of providing a legal and moral right to act preventatively.
\end{abstract}

\section{Introduction}

The instances of terrorist attacks directed primarily against civilians have regenerated political, legal and other scholarly debate regarding limits on the use of force in both international and domestic contexts. In particular, the law governing the right to resort to force - jus ad bellum - has been subject to significant moral, political and legal critique since the tragic events of September 11. Amidst rising international religious-based terrorism and growing measures to counter this threat, a pressing debate is whether anticipatory self-defence and pre-emption are legitimate frameworks for action in international law. September 11 events have also highlighted differences amongst scholars about whether states may respond with force if a non-state actor emanating from inside the borders of another state subjects them to a terrorist attack.

Against this background of the contentious issue of the conditions of permissible use of force, this commentary examines the 'strict scrutiny' approach to self-defence as proposed by Professor Amos N. Guiora and analyses whether it provides for a clear guideline as to when states may carry out pre-emptive and

* Department of International Relations, Bilkent University, Turkey. E-mail: mkinaci@bilkent.edu.tr. 
anticipatory action against a non-state actor. It first reviews the existing concepts of the right of self-defence and pre-emption under international law with special emphasis on the prevailing debates stemming from contesting interpretations of the related law. Parallel to Professor Guiora's analysis of the matter, in order to understand the international legal limits on combating terrorism, the commentary will consider the contemporary codified international law, mainly the UN Charter; customary international law, specifically the Caroline Doctrine as well as post-9/11 Security Council resolutions, primarily Resolutions 1368 and 1373. In addition, the relevant decisions in international litigation, particularly the Nicaragua decision of the International Court of Justice (ICJ) and state practice will be given special attention to shed light to the application of the conditions for admissible use of force in specific instances of the use of force.

The second part of the commentary shall focus on Professor Guiora's processbased 'strict scrutiny' approach to pre-emptive self-defence. The core argument of this approach is that a state can act earlier than permitted under prevailing international law against a non-state actor so long as the act is 'based on reliable, viable, valid, and corroborated intelligence presented to a court of law', which in turn would provide for 'an institutional check on the executive'. After critically assessing the merits and applicability of Professor Guiora's proposal, the commentary will end with concluding remarks on the parameters of pre-emption in a world where the nature of threats has changed drastically.

\section{Use of Force and Right to Self-Defence Doctrine in International Law}

\section{A. Prohibition on the Use of Force}

Most of the contemporary international legal rules, particularly 'the law and customs of war', were devised to prevent the type of devastation and horrors witnessed through much of history. Similarly, being a product of the desire to prevent recurrence of the conflicts that had given rise to the Second World War, the UN Charter established a normative order that strictly restricts the use of force in international relations. The ban on the use of force is laid down by Article 2(4) of the charter, which requires that states 'refrain in their international relations from the threat or use of force against the territorial integrity or political independence of any state, or in any other manner inconsistent with the Purposes of the United Nations.'

The prohibition of the use of force was a rule of pre-charter customary international law. Permissible forms of self-help, ${ }^{1}$ however, had relatively a wider base in the pre-charter period. ${ }^{2}$ In this sense, the charter's stipulation of the ban

1 Self-help may generally be defined as forcible measures to redress violations of the law.

2 For detailed exploration of the concept, see H. Kelsen, The Law of the United Nations (1952) 8-9. 
represented a radical departure from traditional legal concepts like 'just war' and lawful reprisals, since it significantly limited the circumstances under which the use of force is legally admissible. ${ }^{3}$ Read together with the authoritative General Assembly resolutions, such as the Declaration on Principles of International Law (GA Res. 2625 XXV 1970) and the Definition of Aggression (GA Res. 3314 XXIX 1974), Article 2(4) prohibits all unilateral use of force - employed directly or indirectly. Thus, Article 2(4) stipulates a general proscription of the use of force. More precisely, it extends the prohibition of force beyond war to include other types of unilateral use and threat of force. It therefore endows the prohibition of force as a general and authoritative principle. ${ }^{4}$

The substantial majority of legal scholars attribute the norm contained in Article 2(4) a jus cogens character. ${ }^{5}$ The jus cogens status of Article 2(4) is also confirmed in the Nicaragua judgment of the ICJ, whereby it referred to statements by government representatives who considered the prohibition of force in Article 2(4) as not only a principle of customary international law, but also 'a fundamental and cardinal principle of such law'. ${ }^{6}$ The court also inferred the opinio juris of states from the consent given to numerous General Assembly resolutions that reiterated the norm of the prohibition of force, ${ }^{7}$ in particular the $1970 \mathrm{Dec}-$ laration on Principles of International Law, which was adopted by consensus. In addition, the court referred to the views of the International Law Commission on the jus cogens character of the provisions of Article 2(4). ${ }^{8}$ By virtue of being a 'peremptory norm' of international law, therefore, the rule allows for no derogation. As such, it can only be changed or overridden by another peremptory norm. ${ }^{9}$

The charter allows for two exceptions to the general prohibition on the use of force: individual and collective self-defence under Article 51, and enforcement measures authorised by the Security Council in response to 'any threat to the peace, breach of the peace or act of aggression' under chapter VII (and for the regional organisations under chapter VIII). The charter is fairly openended regarding the Security Council's power to authorise force 'to maintain or restore international peace and security' (Article 42), when it determines there is a 'threat to the peace, breach of the peace, or act of aggression' (Article 39). It does not furnish explicit definitions as to what constitutes a threat to peace,

3 See L. Henkin, 'Use of Force: Law and US Policy', in L. Henkin et al., Right v. Might: International Law and the Use of Force (1991) 37.

4 Ibid., p. 38.

5 See, e.g. M. N. Shaw, International Law (3rd edn., 1991) 686; A. Cassese, International Law in a Divided World (1994) 141.

${ }^{6}$ Military and Paramilitary Activities in and against Nicaragua (Nicaragua v United States), Merits, ICJ Reports (1986), para. 190.

7 See, e.g. GA Res. 290 (IV), 1 December 1949; 378 (V) A, 17 November 1950; 380 (V), 17 November 1950; 2625 (XXV), 24 October 1970; 3314 (XXIX), 14 December 1974; 42/22, 18 November 1987.

8 Nicaragua case, op. cit., fn. 6.

9 H. Duffy, The 'War on Terror' and the Framework of International Law (2005) 147. 
a breach of the peace or an act of aggression. It leaves this completely to the judgment of the Security Council. In contrast, the UN Charter is rather restrictive with respect to the use of force by states. It considerably confines the legitimate self-help measures by allowing for only one condition as an exception to the prohibition of the use of force, and in fact attaching it back to the Security Council by stipulating in Article 51 that the unilateral measures in the exercise of the right of self-defence 'shall be immediately reported to the Security Council'.

\section{B. Self-Defence in International Law}

Self-defence is a kind of self-help 'against a specific violation of the law, against the illegal use of force, not against other violations of the law'. ${ }^{10}$ It is self-evident from the term that the defensive intent constitutes its core element. Hence, selfdefence excludes both acts of retaliation and punishment in response to a past attack, and also acts of deterrence against possible future attacks. ${ }^{11}$ With respect to the former acts, the Declaration on Principles of International Law of 1970-a General Assembly resolution, which is widely considered to be the interpretation of the general international law, ${ }^{12}$ asserted that 'states have a duty to refrain from acts of reprisal involving the use of force'. ${ }^{13}$ In addition to being the only exception to the general ban on the unilateral resort to force, self-defence is also the exception to the 'general duty of all states to respect the territorial integrity of other states'. ${ }^{4}$

10 H. Kelsen, Principles of International Law (1952) 60; see also A. V. W. Thomas and A. J. Jr. Thomas, Non-Intervention, The Law and Its Import in the Americas (1956) 79.

11 This commentary defines deterrence as the act or process of discouraging and preventing an action from occurring. 'Acts of deterrence' in this context refer to the use or threatened use of force for political purposes. They entail increasing military strength of a state in order to be prepared to inflict unacceptable damage on an aggressor and making sure that the potential aggressor is aware of the risk, so that he refrains from aggression. Thus, 'acts of deterrence' include actions by which governments threaten an immense retaliation if attacked, such that aggressors are deterred if they do not wish to suffer great damage as a result of an aggressive action.

12 Although General Assembly resolutions are not binding on states, there is a general agreement on the authoritative character of the resolutions on notions like non-use of force, intervention, self-determination and human rights. In this respect, they are argued to represent concrete interpretations of the charter and assertions of general international law. For example, Schachter points out that "[s]uch resolutions "declared the law" either in general terms or as applied to a particular case. Neither in form nor in intent were they recommendatory.' O. Schachter, International Law in Theory and Practice (1991) 85.

13 General Assembly Resolution 2625 (XXV), Declaration on Principles of International Law Concerning Friendly Relations and Co-operation among States in Accordance with the Charter of the United Nations, 24 October 1970.

14 R. Jennings and A. Watts, Oppenheim's International Law, Volume I (1992) 421. 
(i) Article 51

Article 51 of the UN Charter specifies the conditions under which individual states may resort to force. It provides that

Nothing in the present Charter shall impair the inherent right of individual or collective self-defence if an armed attack occurs against a Member of the United Nations, until the Security Council has taken measures necessary to maintain international peace and security.

There has been considerable controversy regarding Article 51, especially with regards to what is meant by 'armed attack'. Although generally speaking, by virtue of Article 2(4), it can be defined as the use of force against a state's territorial integrity and political independence, its exact scope is still in dispute. For example, in its Nicaragua judgment, the ICJ found that sending armed bands or mercenaries into the territory of another state constituted an armed attack, while supply of arms or logistical support by itself did not amount to an armed attack. ${ }^{15}$ Along with the scope of 'armed attack', another contentious issue pertains to whether use of the right of self-defence is confined to the circumstances, whereby an armed attack has already occurred or whether this right can be invoked in anticipation of such an attack.

On the one hand, there are those who argue that Article 51, read in conjunction with the general prohibition of the use of force set out in Article 2(4) and interpreted in the light of the drafting history of the charter, limits the invocation of such a right to cases where an actual armed attack has actually occurred, ${ }^{16}$ rather than being threatened. According to this restrictionist view, in contrast to Article 2(4) and Article 39 for example, Article 51 leaves out any reference to the 'threat' of an attack, and thus, incidence of an armed attack is certainly meant to be the required condition.

On the other hand, there are legal scholars who argue that Article 51 should not be interpreted as excluding the right to anticipatory self-defence in the case of an imminent danger of attack. This view rejects the restrictive interpretation of the word 'if', as it is employed in Article 51, as meaning 'if and only if'. These scholars point out that by qualifying the right of self-defence as 'inherent', Article 51 indicates the existence of a right of self-defence in pre-charter customary international law, according to which preventive measures are permitted. The argument goes, by the term 'armed attack', Article 51 refers merely to one situation, whereby a state could invoke the right of self-defence. ${ }^{17}$ Supporters of

15 Nicaragua case, op. cit., fn. 6, para. 195.

16 I. Brownlie, International Law and the Use of Force by States (1963) 265; H. Kelsen, The Law of the United Nations (1951) 797-798; H. Lauterpacht (ed.), L. Oppenheim, International Law: A Treatise, Vol. I - Peace (1955) 299; L. Henkin, How Nations Behave: Law and Foreign Policy (1979) 140-143.

17 D. W. Bowett, Self-Defence in International Law (1958) 185; R. Higgins, The Development of International Law Through the Political Organs of the United Nations (1963) 
this view refer to the legal criteria for permissible self-defence as formulated by US Secretary of State Daniel Webster, in the Caroline incident, ${ }^{18}$ as reflecting the authoritative customary law. ${ }^{19}$ According to this formulation, the anticipatory self-defence is admissible, when 'the necessity of that self-defence is instant, overwhelming, and leaving no choice of means and no moment for deliberation'. ${ }^{20}$ Thus, the two conditions for anticipatory self-defence are necessity and proportionality: First, the state resorting to use of force in self-defence needs to demonstrate that the use of force by the other state is imminent and that there is no available remedy other than use of force to prevent the attack. Second, the state using force in self-defence is required to take action proportionate to the threat in question.

There has been no authoritative decision in international litigation on the question of anticipatory self-defence. In the Nicaragua case, the ICJ left the question open, by stating that

...the issue of the lawfulness of a response to the imminent threat of an armed attack has not been raised. Accordingly the Court expresses no view on that issue. ${ }^{21}$

The court's position on this issue is unclear, given that Judge Schwebel, in his dissenting opinion in the Nicaragua case, argued that Article 51 does not circumscribe self-defence to a situation 'if, and only if armed attack occurs' ${ }^{22}$

\section{(ii) Anticipatory self-defence and state practice}

Although opponents of anticipatory self-defence point out the dangers of unilateral judgment of a state regarding the existence of a threat of an attack, the general wisdom seems to side with the argument that it is unreasonable for a state to wait until attacked to invoke self-defence. Given the sophistication of today's weaponry and the vast destructive capabilities of the contemporary weapons systems, the argument in favour of a more flexible interpretation of Article 51 has generated a general acceptance, particularly in the aftermath of September 11,

201; for a similar argument, see also G. M. Travalio, 'Terrorism, International Law and the Use of Military Force', (2000) 18 Wisconsin International Law Journal 145.

18 Caroline incident refers to the British attack in 1837 on a vessel owned by US nationals, Caroline, on the basis of its alleged support to the anti-British insurgency in Canada and with a claim to right to self-defence.

19 R. Y. Jennings, 'The Caroline and McLeod Cases', (1938) 32 AJIL 92; O. Schachter, International Law in Theory and Practice (1991) 151; A. C. Arend and R. J. Beck, International Law and the Use of Force, Beyond the UN Charter Paradigm (1993) 72; T. L. H. McCormack, Self-Defence in International Law, The Israeli Raid on the Iraqi Nuclear Reactor (1996) 247.

20 See note of Webster to British authorities, 27 July 1842, quoted in T. L. H. McCormack, Self-Defence in International Law, The Israeli Raid on the Iraqi Nuclear Reactor (1996) 183.

21 Nicaragua case, op. cit., fn. 6, para. 194.

22 Nicaragua case, op. cit., fn. 6. 
that states may resort to force in self-defence rather than wait for perhaps a devastating first strike. ${ }^{23}$

Nonetheless, the post-1945 state practice demonstrates that the existence of such a customary norm as a legal basis to resort to force is at best doubtful. The most representative case is Israel's bombing of the nuclear reactor under construction in Iraq in 1981, with the claim that the nuclear reactor in question would be producing nuclear material, which would be used in building nuclear weapons to attack Israel. Justifying the action on the basis of anticipatory self-defence, the Israeli ambassador to the UN stated that 'Israel was exercising its inherent and natural right of self-defence, as understood in general international law and well within the meaning of Article 51 of the Charter. ${ }^{, 24}$ During the Security Council debates, taking a restrictive position on Article 51, i.e. confining the right to selfdefence to cases where there is an actual armed attack, several states, among which were Syria, Guyana, Pakistan, Spain and Yugoslavia, condemned the Israeli action. While some other states did not argue against a right of anticipatory self-defence, they pointed out that Israel failed to meet the 'necessity' requirement. The representative of Sierra Leone, for example, making reference to the Webster formula, maintained that 'the plea of self-defence is untenable where no armed attack has taken place or is imminent' and deemed the Israeli action as 'plainly an act of aggression'. ${ }^{25}$ In the same vein, the British representative held that the Israeli attack 'was not a response to an armed attack' and that '[t]here was no instant or overwhelming necessity for self-defence'. He expressed that the Israeli use of force 'cannot find a place in international law or in the Charter' ${ }^{26}$ Consequently, the Security Council unanimously condemned Israeli action and found 'the military attack by Israel in clear violation of the Charter of the United Nations and the norms of international conduct' ${ }^{27}$ Expressing the US view in the aftermath of the adoption of the resolution, the US Ambassador asserted that 'Israeli actions violated the Charter of the United Nations', particularly because Israel did not exhaust peaceful means for the resolution of this dispute. ${ }^{28}$ Thus, by implication, the US view too underlined the Israeli failure of fulfilling the conditions of necessity and immediacy.

Thus the majority of states have been disinclined to admit the permissibility of such a right before September 11. In addition, there has not been a doctrinal consensus within the academic debate. At a minimum, however, the general agreement is that if such a right exists, the circumstances under which it can be invoked remain to be limited to the Webster formula. More specifically, necessity and proportionality are commonly recognised as the required conditions of exercise of self-defence under customary international law and the UN Charter.

23 See, e.g. T. M. Franck, Recourse to Force: State Action against Threats and Armed Attacks (2002) 98.

24 UN doc. S/PV. 2280 (1981), p. 16.

25 UN doc. S/PV.2283 (1981), p. 56.

26 UN doc. S/PV.2282 (1981), p. 42.

27 SC Res. 487 (1981).

28 UN doc. S/PV.2288 (1981), p. 14. 
This interpretation, however, is challenged with the National Security Strategy (NSS) of the USA (2002) issued under the Bush administration, which argued for a more expansive view of pre-emptive action. The NSS of 2002 stated that 'as a matter of common sense and self-defence, America will act against such emerging threats before they are fully formed. ${ }^{29}$ It argued that ' $[\mathrm{t}]$ he greater the threat, the greater is the risk of inaction - and the more compelling the case for taking anticipatory action to defend ourselves, even if uncertainty remains as to the time and place of the enemy's attack.' Therefore it claimed 'the United States will, if necessary, act pre-emptively' in order to prevent hostile acts by enemies. The NSS argued that the concept of imminent threat must be adapted to the capabilities and objectives of today's adversaries' ${ }^{30}$

(iii) Normative developments after September 11

The day after the September 11 events, the Security Council unanimously passed a resolution, which recognised 'the inherent right of individual and collective selfdefence in accordance with the Charter', condemned the terrorist attacks of 9/11 and stated that it 'regards such acts, like any act of international terrorism, as a threat to international peace and security'. It also expressed the council's 'readiness to take all necessary steps to respond to the terrorist attacks of 11 September 2001, and to combat all forms of terrorism', and recognised that Article 51 extended self-defence to the use of force against 'those responsible for aiding, supporting or harbouring the perpetrators, organisers and sponsors of these acts will be held accountable. ${ }^{31}$

Despite the reference to the right of individual and collective self-defence in its preamble, the resolution was not adopted under chapter VII and did not contain any explicit authorisation of force in its operative part. This remains in contrast, for example, with Resolution 678 (1990) adopted after Iraq's invasion of Kuwait, whereby the Security Council authorised all member states cooperating with Kuwait to use 'all necessary means' to force Iraq to implement the council resolutions and restore international peace and security. By leaving the question of whether the conditions for self-defence had been satisfied open, the Security Council's position remained ambiguous on the issue of the use of force in self-defence against terrorism. Moreover, this resolution was adopted on the following day of the terrorist attacks, at a time the identities of the perpetuators were not known with certainty. Further, as established, the norm Article 2(4) has universal and imperative applicability, the use of force against a sovereign state requires absolute clear authority, and thus would have been explicitly expressed if intended. ${ }^{32}$ All in all, legally speaking, Resolution 1368 did

29 National Security Strategy of the United States (2002), p. ii.

30 National Security Strategy of the United States (2002), p. 15.

31 SC Res. 1368 (2001).

32 G. Ulfstein, 'Terrorism and the Use of Force', (2003) 34 Security Dialogue 155. 
not in itself recognise the US's right to resort to force against Afghanistan and other states that may be claimed to have contributed to terrorism.

On 28 September 2001, the Security Council adopted Resolution 1373. Reiterating the main points of the earlier resolution, Resolution 1373 put a number of requirements on states to prevent the financing of terrorist acts and the recruiting of terrorists. In contrast to Resolution 1368, this resolution was adopted under Chapter VII. Like Resolution 1368, however, it made reference to the right of self-defence in its preamble and did not provide for authorisation of force.

Although these resolutions were not direct authorisations of force, they nevertheless established a legitimate political ground for the following US-led intervention in Afghanistan by linking the right of self-defence and terrorism. ${ }^{33}$ In addition, subsequent resolutions and related statements recognised regime responsibility for failure to prevent or punish such actions. Further, the Security Council expressed its support for 'international efforts to root out terrorism, in keeping with the Charter of the United Nations' in Resolution 1378 (2001). Hence, all these resolutions provided legitimacy for the resort to force against terrorist bases on the territory of states that are unable or unwilling to prevent terrorist actions. As a result, once the USA established the Taliban government's substantial involvement in providing support to the activities of al-Qaeda through credible evidence, there was no opposition to the US position among the Security Council members. After the fall of the Taliban regime, the UN authorised the establishment of an International Security Assistance Force (ISAF) for maintenance of security in Kabul and in surrounding areas. By the same resolution, the Security Council also authorised participating states 'to take all necessary measures to fulfil its mandate'. ${ }^{34}$

The Security Council responses and resolutions, together with wide state support evince that the US military campaign in Afghanistan was widely regarded legal as well as legitimate despite the lack of direct authorisation of force. Hence, one may point to a normative trend regarding the scope of self-defence towards extending the concept of 'armed attack' to include acts of terrorism by non-state terrorist organisations, and by extension, the permissibility of the use of force against those regimes that have failed to prevent terrorist attacks.

The reactions to the US-led invasion of Iraq, however, stand in stark contrast to the military intervention in Afghanistan. Although the USA argued for a right of pre-emptive self-defence under international law against the threat of weapons of mass destruction (WMD) and terrorism during the months preceding the war, it is notable that it did not employ this line of legal reasoning for its military action against Iraq. Instead, the USA asserted that its action was authorised under the existing Security Council resolutions, ${ }^{35}$ most notably by Resolution 678 of

33 A. Roberts, 'Law and the Use of Force After Iraq', (2003) 45 Survival 37.

34 SC Res. 1386 (2001).

35 For a detailed account of the legal basis of the invasion argued by the USA, see UN doc. $\mathrm{S} / 2003 / 351$. 
1990. ${ }^{36}$ Similarly, the UK and Australia did not invoke self-defence. ${ }^{37}$ They argued that Iraq's failure to uphold the 1991 cease-fire obligations of Resolution 687 (1991) had revived the authority to use force under Resolution $678 .{ }^{38}$ Merits of the US legal argument - that there was no need for another resolution authorising force after Resolution 1441 (2002), which determined that Iraq was in material breach of its obligations, and the issue of whether or not 'revival' of the previous authorisation of force is viable, are out of the scope of the present commentary. This said, it has to be noted that there was explicit opposition at the UN to the US legal argument for the invasion. Many states strongly objected to the intervention on legal grounds. The then UN Secretary-General Kofi Annan also expressed his concern prior to invasion that '[i]f the US and others were to go outside the Council and take military action it would not be in conformity with the Charter. ${ }^{39}$ Finally, there was significant public opposition to the war in many states. ${ }^{40}$ Consequently, the US action in Iraq was largely considered not only unlawful, but also illegitimate to the extent that it not only lacked an explicit authorisation from the Security Council, but also was undertaken despite strong expression of disapproval.

Thus far, the Security Council has not demonstrated any willingness to assert a wide right to self-defence against terrorism. The subsequent Security Council resolutions in response to various terrorist attacks in the aftermath of 9/11, such as the attack on a Bali night club (Resolution 1438), the act of hostage taking in Moscow (Resolution 1440), bomb attack in Colombia (Resolution 1465), terrorist acts in Kenya (Resolution 1450) and the bomb attacks in Istanbul (Resolution 1516), condemned the acts and repeated that such acts are regarded as a threat to international peace and security. But no reference was made to the right to self-defence. The absence of reference to self-defence in similar contexts may be taken as a manifestation that the right to use force in self-defence against past terrorist attacks remains exceptional.

\section{3. 'Strict Scrutiny' Test: Is It Feasible?}

Professor Guiora proposes a judicial check on the executive's decision of preemptive action, which will eventually lead to an 'objective legal criteria for operational counterterrorism'. He argues that this process-based approach to

36 Resolution 678 authorised a coalition of states to repel Iraq from Kuwait and to restore international peace and security.

37 For UK's legal analysis, see UK Attorney General, P. Goldsmith, 'Legal Basis for Use of Force against Iraq', 17 March 2003. Available at <http://www.number10.gov.uk/ output/Page3287.asp $>$.

38 UN docs. S/2003/350 and S/2003/352.

39 Kofi Annan, Press Conference, The Hague, The Netherlands, 10 March 2003. Available at $<$ http://www.un.org/apps/news/infocusnewsiraq.asp?NewsID $=421 \&$ sID $=7>$.

40 See, e.g. 'Across Europe, Millions Protest a War in Iraq', Washington Post, 15 March 2003, A17. 
pre-emptive self-defence against non-state actors can overcome the insufficiency of the current international law - UN Article 51, Caroline Doctrine, and the post9/11 Security Council Resolutions 1368 and 1373 - in permitting a state to act early enough. Crucial to his proposal is 'reliable, viable, valid and corroborated intelligence' reviewed by a court of law.

\section{A. Merits of the Approach}

Guiora's analysis focuses on terrorist bombings, which he considers as 'the new threat' and the most solid materialisation of contemporary terrorism that causes 'the indiscriminate killing of innocent civilians'. Guiora confines 'the unseen enemy' to the terror bombings and distinguishes it, for example, from airplane hijackings on the basis that 'passengers knowingly accept the risk when they choose to fly'. This limitation of contemporary threats and risks does not appear convincing. In a similar vein, one can argue, for example, that people going to shopping malls or crowded market places also accept the high risk of a terror bombing, a suicide bombing or remote control bombings in such places. Thus, by this logic, terror bombing can also be excluded from the definition of 'unseen enemy'. This commentator believes that common to both acts is the aim to kill or harm civilians indiscriminately in essence. Therefore the distinguishing element as described by Professor Guiora is methodologically flawed.

Secondly, Guiora proposes 'active self-defence' as a tool to tackle terrorist bombings. Active self-defence, Guiora argues, is aimed either at deterring terrorists or preventing terrorism. Guiora's conception of active self-defence does not distinguish between pre-emptive and preventive action. In this sense, he seems to consider active self-defence as a broader concept that includes both preemptive/anticipatory and preventive self-defence. Pre-emptive or anticipatory self-defence as formulated in Caroline Doctrine entails action when the imminence of threat is determined by credible intelligence, whereas preventive strike anticipates a latent armed attack that is merely 'foreseeable' or 'conceivable'. Striking first in order to pre-empt an enemy that has troops massing along your border is one thing. Striking first against a state that has never even explicitly threatened your sovereign territory, except in response to your own threats, because you believe it may threaten you in an unspecified future, is something very different. Thus, the distinction between the two concepts is significant. The notion Guiora introduces may be said to be his inclusion of defensive action against a non-state actor into the concept of active self-defence. However, the controversial matter in legal and policy terms is not so much focused on whether a self-defence action - after an armed attack or in anticipation of an attack - can be carried out against a non-state actor. As discussed above and also in Guiora's analysis, post-September 11, Security Council resolutions have in effect extended the definition of armed attack to include acts undertaken by non-state actors operating from the territory of a state that is unable or unwilling to prevent terrorist acts. The extension of the right to self-defence as such has largely remained 
controversy-free, once world public opinion was convinced regarding the reliability and credibility of the intelligence that led to a defensive action, particularly in Afghanistan.

The contested issue after $9 / 11$ is not also whether anticipatory self-defence is permissible in accordance with the Caroline Doctrine or not. Rather, the gist of the debate in academic and policy circles has centred on the issue of preemption as depicted by the Bush doctrine and in the US National Security Strategy. This formulation of anticipatory self-defence is similar to Guiora's approach and is far broader than any formulations previously claimed. It is the removal of the element of immediacy, which in turn dilutes the criterion of necessity, that lies at the basis of the recent discussions. Where there is a credible evidence of an imminent threat and hostile intent, and when the threatened state has no alternative remedy, there is little objection to a state's use of force both as a matter of common sense and law. Nonetheless, given the changed nature of the threats, in particular emergence of new threats such as proliferation of WMD and terrorism, it is possible to conceive of threats that are real but not imminent. The problem with the expansive formulation of anticipatory self-defence, however, is less with the requirement of immediacy per se, when there is credible evidence of the reality of the threat in question - determined by capability and hostile intentions - and when there is no alternative course of action. ${ }^{41}$ The controversy arises as to the agency of the decision, i.e. whether the decision of a preventive offensive war can be taken unilaterally. In this sense, Guiora's argument does not address the heart of the controversy.

Moreover, such loose understanding of pre-emptive action not only considerably removes the restraints on 'when states may use force', but also 'undermines the restraints on how states may use force'. ${ }^{42}$ A subjective determination of a possible attack logically leads to a subjective determination of the amount of force required for pre-empting a possible attack. Thus Guiora's conception of active self-defence troubles not only the immediacy and necessity criteria, but also the proportionality component of the traditional understanding of anticipatory selfdefence.

Thirdly, Guiora asserts that when active self-defence violates sovereignty of a state, 'there is an implicit determination that the violated state is a failed state'. Nonetheless, this statement is not substantiated by the recent cases of active selfdefence. For example, one of the political justifications presented by the US administration for their action against Iraq was Saddam Hussein's alleged support to terrorism. Iraq under the rule of Saddam however, was neither a failed nor a collapsed state by commonly accepted standards of the term. ${ }^{43}$ In a similar vein, the example Guiora provides, namely the Israeli attack on terrorist bases in Syria

41 G. Evans, 'When Is It Right to Fight?', (2004) 46 Survival 65.

42 M. E. O'Connell, 'The Myth of Preemptive Self-Defence', (2002) ASIL Task Force Papers (2002) 19. Available at <http://www.asil.org/taskforce/oconnell.pdf $>$.

43 For a detailed study of 'collapsed state', see W. Zartman, Collapsed States: The Disintegration and Restoration of Legitimate Authority (1995). 
in 2003 and later a nuclear target in Syria in 2007, also is not representative of his argument of failed state. Thus, the most recent cases do not support his assertion.

Finally, it is not clear whether Guiora argues active self-defence only against terrorist bombings carried out by non-state actors. More precisely, does this normative suggestion of anticipatory self-defence based on reliable, viable intelligence apply only to the non-state actors? If this is the case, does this amount to the suggestion that in case of any other threat by a state rather than a non-state actor, are states not allowed to take pre-emptive or - in the framework of Guiora's proposal - preventive action? In other words, is the limitation to terror bombings by non-state actors an attempt to limit the legal grounds for preventive action against a state, or is this limitation meant to provide analytical and methodological rigour and/or vigour?

As regards to the four legs of the strict scrutiny test, the first tenet that 'the state has a fundamental right to active self-defence' appears to imply a right akin to the doctrine of self-preservation, ${ }^{44}$ under which any action taken by a state to remove the potential impairment to its interests, regardless of the immediacy of the threat, is considered legal. The second leg represents a Machiavellian ethic of responsibility, whereby a state's first and foremost responsibility is 'to protect the safety and welfare of its citizens'. This formulation is often employed as a justification for breaking the laws of war. For example, the US decision to drop nuclear bombs on Hiroshima and Nagasaki in 1945 can be said to have risen from such a rationale. The problem is that while this formulation may instruct the decision makers to consider the consequences of a given action, it does not guide them to weigh the consequences. ${ }^{45}$ This state-centric approach with its focus on distinctive morality considers no community beyond state borders. Such a Hobbessian understanding of international politics assumes states as like units in terms of their principle motive of survival. According to this logic, in principle then, Iran, for example, may also consider resorting to force against its perceived threats emanating from Israel and/or the USA. Concerning the third leg of Guiora's strict scrutiny test, it is not clear how he defines 'morality'. This ambiguity also appears with regards to the rule of law. Is it jus ad bellum or jus in bello that is referred to? The final leg of the strict scrutiny test - reliable, viable, valid and corroborated intelligence information - actually goes without saying as a necessary requirement of any military action. Not only reliable information is required for the operational counterterrorism to be 'effective', but also the assertion follows from the

44 According to the doctrine of self-preservation, a state may violate any norm of international law or infringe any right of another state, if the elimination of violation of its vital interests and its preservation requires such action. Scholars, who are of the opinion that there is a right to self-preservation, assert that this right has priority among all the fundamental rights of states. For example, the English jurist Hall states that in the last resort almost the whole of the duties of states are subordinated to the right of self-preservation.' For the doctrine of self-preservation in general, see Kelsen, op. cit., fn. 10, pp. 58-59; Lauterpacht (ed.), op. cit., fn. 16, pp. 297-304.

45 For an excellent discussion of many of the prominent realist thinkers, see M. J. Smith, Realist Thought from Weber to Kissinger (1986). 
overall philosophical foundation of this approach: Insofar as the state's primary responsibility is to protect the safety of its citizens, a state cannot risk the lives of its citizens based on unreliable and uncertain intelligence.

Lastly, there is an inconsistency of ideas and a methodological error in the four legs of the strict scrutiny test, since the first two constitute assumptions rather than testable criteria. On the other hand, although the aim is stated to be able to objectify the early use of force for prevention of a terrorist bombing by a nonstate actor, the first three legs will inevitably remain subjective, since these cannot be presented to the court of law. The only part that can be subject to review by a court of law is the last leg concerning 'reliable, viable valid and corroborated' intelligence.

In the final analysis, 'substantive thesis' of Guiora's proposal that interpretative errors and mistakes of analysis of the intelligence 'can lead to tragic mistakes' has unfortunately proven to hold true in the case of Iraq, assuming that the military action against Iraq was indeed undertaken based on the available intelligence, rather than any other considerations. To minimise the operational error, Guiora suggests a set of standards for admissibility of such an action with understandable righteous intentions. Guiora also points out that his proposal aims to achieve the balance between the state's need to protect itself, i.e. self-defence, and its obligation to protect innocent lives. This aspect, however, is precisely the rationale behind the proportionality requirement of the Caroline Doctrine, and thus, the necessary regulator already exists in customary international law.

\section{B. Applicability}

Perhaps the most confusing part of Professor Guiora's approach is the ambiguity of its area of application. The terminology of the American political system in Guiora's model implies that the proposed test is exclusively considered within the context of the USA. Guiora states, for example, that 'a President that acts in contravention to the court's ruling could be liable for committing a crime and possibly impeachable offense.' This approach has no applicability, say for example in the United Kingdom, let alone other states.

If on the other hand, this model is to be followed by all nation states when they feel threatened, would it be considered a lawful response if an Iranian court of law decides that a pre-emptive or preventive action can be considered to curb the Israeli threat based on viable, reliable intelligence? Would such a decision be accepted as objective and justify Iranian military action? Or is this approach limited to democratic states? If so, on what criteria are states judged to be democratic or not? Would it not then contradict with the fundamental constituting principle of the international order, namely 'sovereignty'? More specifically, what would be the repercussions of such unilateralism and widespread acceptance of such a model for international order and justice? The present commentator believes that admittance of such a broad right, subjected to the review of a national court, would amount to legitimisation of potential future preventive strikes by others, 
possibly in the most conflict-ridden regions, such as the Middle East, South and East Asia. In essence, it would provide a basis for any state, where its intelligence has been admitted by a court of law, to attack another state harbouring a nonstate actor suspected of a possible future attack. These critical implications of the application of strict scrutiny test are not addressed in Guiora's analysis.

Another question related to the applicability of the strict scrutiny test is why a court of law would be any more objective when the question is national security. After all, interpretation of law also involves political considerations. Further, Guiora argues that present international law, including customary international law, does not enable governments to act earlier. However, he asserts that the adoption of a process of judicial authorisation would ensure lawful responses to terrorism. These two assertions are contradictory, for if the law does not allow for an earlier action, the question remains how a court of law's decision would legalise operational counterterrorism in the absence of relevant law, since courts decide on the basis of the existing law?

On the other hand, the executive decides to undertake military action on intelligence as well. In Guiora's view, operational decisions are taken subjectively by commanders and decision makers. However, the present commentator believes that the issue of subjectivity in Guiora's analysis is confusing, as illuminated by the examples he gives. Guiora states that President Clinton's authorisation of bombing of a building in Sudan, which was claimed to be a chemical-making factory, turned out to only house a pharmaceutical company. By his own admission, Clinton's decision to use force was based on the intelligence information. In this sense, the issue is not subjectivity as the decision was taken objectively given the available intelligence. The problem, however, as Guiora points out, remains the reliability of the information. Otherwise, his argument can be taken to mean that the executive can distort the intelligence available, and in this specific example, that President Clinton authorised the bombing although he knew it was only a pharmaceutical company, and thus his decision was not objective but a subjective decision taken with other considerations. If this is not what the strict scrutiny test suggests, then the methodological problem is not the objectivity of the decision makers, but the reliability, viability and validity of intelligence, which can only be determined by the intelligence community rather than a court.

Finally, Guiora asserts that intelligence must be reliable, viable, valid and corroborated for it to be considered by a court. If the reliability of the intelligence information is ascertained beforehand - although not clear how this is established and by whom before it is presented to the court of law - the role and the use of the court, and thus Guiora's model, become very unclear.

\section{Concluding Remarks}

Ultimately, with its applicability limited to the USA, Guiora's proposal appears to justify the American decisions to resort to preventive force. If the idea behind the proposal as stated by Guiora is to rationalise and justify use 
of force by objectifying the intelligence through the review of an American court, the strict scrutiny test would remain a very naive approach at a time when American credibility is shattered with the Guantanamo and Ebu Garib scandals, death of 1 million civilians in Iraq by some accounts, and more recently with President Bush's veto of a bill that sought to prohibit the CIA from using torture techniques, such as waterboarding - a technique in which restrained prisoners are threatened with drowning. If on the other hand, this course is to be followed by other states, it would not be far-fetched to argue that all formal constraints on war-making would be defunct.

As the former UN Secretary-General Kofi Annan asserted, the right to use force preventively sets precedents for a 'proliferation of the unilateral and lawless use of force, with or without justifications'. ${ }^{46}$ As mentioned above, the Security Council is broadly empowered by the general language of Article 39, to deem such circumstances sufficient to authorise force. Further, having a quasiconstitutional status, the charter should be interpreted as a document responsive to changing circumstances and challenges of the world. ${ }^{47}$ In fact, the UN practice in the field of international peace and security is replete with instances of Security Council's innovative means to deal with new challenges and threats, including the development of peacekeeping forces, expansion of the concept of 'threat to peace' from inter-state conflict to internal matters, such as human rights violations, and delegation of authority to national forces to carry out chapter VII enforcement measures. Most recently, the Security Council's expansion of the scope of 'armed attack' to include terrorist attacks by non-state entities stands as yet another example of the degree of UN's adaptability to the changing threats. Thus, the point is that it is possible to conceive a multilateral action in order to tackle the emerging threats to international security without undermining the constitutive principles of international order. Consequently, when there is an international organisation which is empowered to act as a world court, there shall be no efficacy of such domestic mechanism in terms of providing a legal and moral right to act preventatively. This proposal if taken to application would unfortunately give an impression to the rest of the world as yet another disguise for the American grand designs, and thus would be another defeat in the 'battle of hearts and minds'.

46 K. Annan, 'The Secretary-General Address to General Assembly,' 23 September 2003. Available at $<$ http://www.un.org/webcast/ga/58/statements/sg2eng030923 $>$.

47 See Franck, op. cit., fn. 23, pp. 5-9. 